\title{
Computed Tomography Imaging Findings of Simultaneous Bifid Mandibular Condyle and Temporomandibular Joint Ankylosis: Case Report
}

\author{
Marcelo Augusto Oliveira SALES ${ }^{1,2}$ \\ Jefferson Xavier OLIVEIRA ${ }^{2}$ \\ Marcelo Gusmão Paraíso CAVALCANTI ${ }^{2,3}$ \\ ${ }^{1}$ Service of Oral and Maxillofacial Radiology, Lauro Wanderley University Hospital, \\ Federal University of Paraíba, João Pessoa, PB, Brazil \\ ${ }^{2}$ Department of Radiology, School of Dentistry, University of São Paulo, São Paulo, SP, Brazil \\ ${ }^{3}$ Department of Radiology, College of Medicine, University of Iowa, Iowa City, IA, USA
}

\begin{abstract}
Bifid mandibular condyle is an uncommon entity described in the literature as having a controversial etiology. Despite the absence of clinical symptomatology, the radiologist must be aware and should have some knowledge of this abnormality, as well its implications regarding functional and morphological changes. TMJ ankylosis is a disabling disease with involvement of the mandibular condyle, articular fossa and base of the skull. The association of bifid condyle with temporomandibular joint ankylosis is rare and must be carefully evaluated. The purpose of this paper is to report a case of simultaneous bifid mandibular condyle and temporomandibular joint ankylosis and to describe its computed tomography imaging findings.
\end{abstract}

Key Words: computed tomography, bifid mandibular condyle, temporomandibular joint ankylosis.

\section{INTRODUCTION}

Bifid mandibular condyle (BMC) is a rare condition (1) and usually has no significant complaints or clinical features, such as pain or restricted movements (2). Although this type of morphological change is generally associated with trauma (3), conditions, such as teratogenic drug use, genetic inheritance, infection and exposure to radiation can also cause the development of this anomaly. Temporomandibular joint (TMJ) ankylosis is a pathological change with bony or fibrous ankylosis with deformity of the articular fossa and mild or severe formation of osseous tissue, impairing functions, such as speech, chewing, and mouth opening (4). This condition could be consequence of trauma, infection or degenerative changes. When ankylosis occurs during the childhood, the patient could show severe facial alterations. According to the reviewed literature, facial trauma in early stages of facial development is the most important etiologic factor of this pathology (5-8).

Computed tomography (CT) imaging brings to radiologists and clinicians the possibility of evaluating complex cases in the maxillofacial field and giving information that leads to more accurate and specific diagnosis of some TMJ pathologic conditions $(6,9)$. This paper reports a case of simultaneous BMC and TMJ ankylosis and to describe its CT imaging findings.

\section{CASE REPORT}

An 8-year-old Caucasian female patient was referred to CT for evaluation of malocclusion and facial asymmetry due to marked deformity of the mandibular arch and deviation to the right side. A total of 60 axial slices with 1-mm slice thickness and $1 \mathrm{~mm}$ of reconstruction interval were obtained.

The analysis of the axial images revealed a hyperdense image in the right TMJ with loss of anatomi-

Correspondence: Dr. M.G.P. Cavalcanti, Departamento de Radiologia, Faculdade de Odontologia, Universidade de São Paulo. Avenida Prof. Lineu Prestes 2227, 05508-900 São Paulo, SP, Brasil. Tel: +55-11-3091-7807. Fax: +55-11-3091-7899. e-mail: mgpcaval@usp.br 
cal landmarks (Fig. 1), shortening of the superior articular space and presence of condylar hyperplasia were observed (Fig. 2). In the left TMJ, there was an alteration in the head of the mandibular condyle with formation of a bifid condyle (Fig. 3). Subsequently, the CT data were transferred to a networked computer workstation. Using volumetric imaging software, based on a stack of contiguous axial transverse scans, simultaneous multiplanar reconstructed CT images (MPRCT) were obtained, creating coronal and sagittal views. These sets of images showed a bifid condyle and its relationship with the articular fossa (left side), as well as the ankylosis (contralateral side), lesion extension and bone involvement. In addition, MPR-CT and 3D-CT clearly depicted the aberrant form of the left condyle with a central notch or groove and the formation of two condylar heads with mediolateral orientation (Fig. 4).

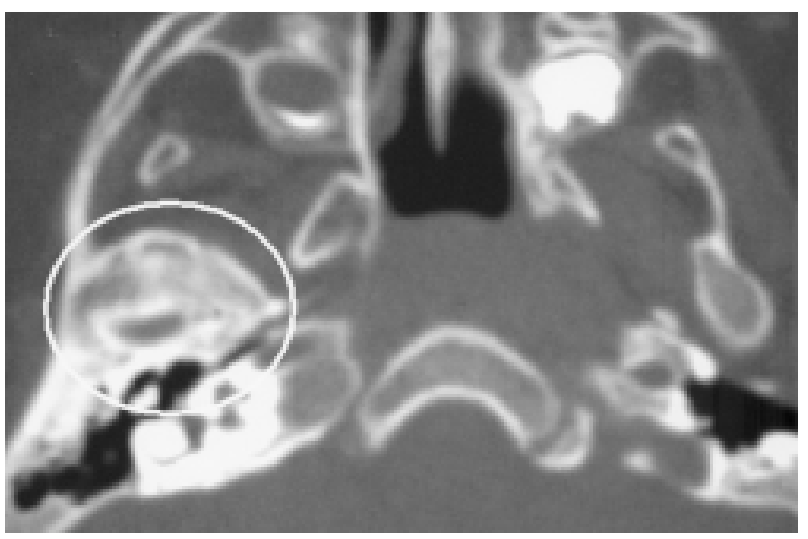

Figure 1. 2D-CT axial view (bone window) shows right TMJ ankylosis with loss of anatomical landmarks (white circle).

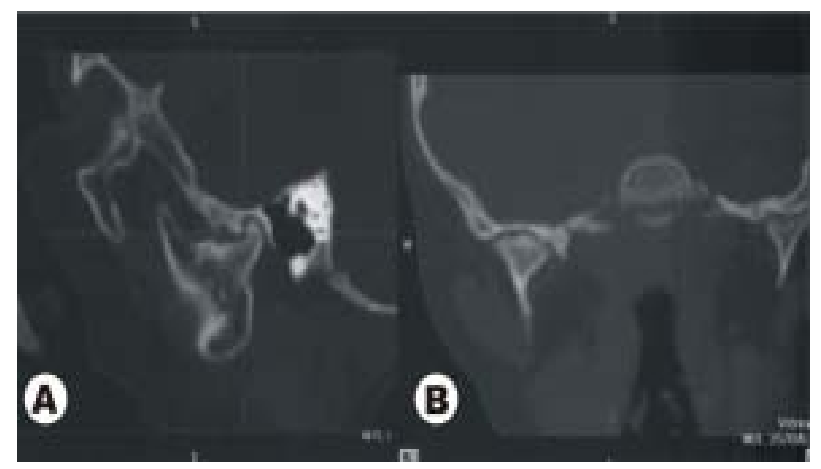

Figure 2. Sagittal (A) and coronal (B) views (bone window) showing shortening of superior articular space (A), and (B) presence of right condylar hyperplasia.

\section{DICUSSION}

According to Blackwood (7), two articulating surfaces of the BMC are divided by a groove and can be orientated mediolaterally or anteroposteriorly, characterizing a specific entity. In this case report, as postulated above, groove formation and presence of medial and lateral head of the left condyle clearly demonstrated the formation of the BMC in the left side, as observed in Figure 1. Only few cases such as this have been reported $(9,10)$. On the other hand, the radiographic appearance of TMJ ankylosis is widely variable with many features. Panoramic views showed that there is a joint deformity, with complete loss of the joint space and abnormal bone formation in/or around the joint, but did not reveal the nature and the extent of the pathology, in particular the medial and lateral extension of the ankylosed bony mass, and its relation to surrounding vital structures. These details were clearly apparent in the coronal CT, which illustrated whether the ankylotic mass was fibrous or bony (11). In our case, it is shown on Figure 2 , where the shortening of the articular space and the presence of abnormal bony outgrowth in the head of right condyle were observed. These findings corroborated the presence of true osseous ankylosis, which were better observed in CT as previously mentioned (6). In our opinion, CT images were helpful in elucidating the detailed state of the hard tissue pathology and provided great visualization of TMJ ankylosis.

Although TMJ ankylosis has clinical symptoms, such as pain, limitation of mouth opening and asymme-

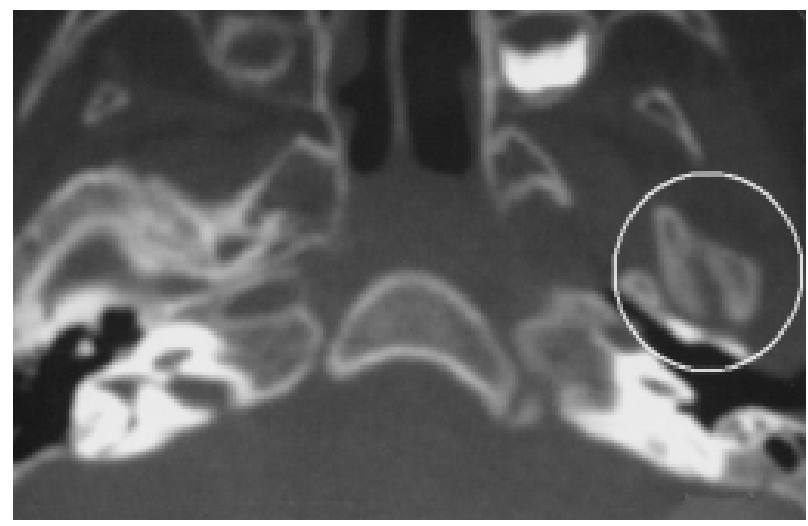

Figure 3. 2D-CT axial view (bone window) demonstrates the bifid mandibular condyle in the left side with mediolateral heads. (white circle). 
try with mandible and chin deviation (12), due to its minimal symptomatology, BMC remains a relatively uncommon entity. In view of this, BMC diagnosis usually relies on radiological rather than clinical evidence. It is usually identified as an incidental finding on panoramic radiographs and thus these findings are exceptional in human remains and living population. This case report illustrates the need for accurate examination of patients with marked facial asymmetry and craniofacial deformities. According to Linnau et al. (13), a simple clinical evaluation does not fully characterize facial fractures or deformities, and the deeper midface is not accessible to physical examination.

The association between BMC and TMJ ankylosis is rare and must be carefully evaluated. The progress of diagnostic imaging has included the development and improvement of new imaging techniques that allow easier and earlier detection of pathological changes that could be extremely hazardous to the patient $(5,14)$. In this field, advances in radiographic modalities and imaging methods have led to various options for visualizing the TMJ. In this regard, good plain skull radiographs are difficult to obtain and are frequently of poor quality. Thus, accurate and detailed examination of the craniofacial skeleton is sometimes an impossible task (15). In This case report, the use of 3D-CT reconstructed images (Fig. 4), enabled the radiologist to visualize and manipulate the image data quickly to get a better visualization of the condyle and its relationship with base of the skull and surrounding structures.

Thus, more details were obtained from the images regarding normal and pathological tissues (16). Additionally, the use of axial and MPR-CT images improved the capacity of the radiologist in determining the actual situation of pathologic tissues and the true extension of the lesions. Furthermore, the association of axial/MPR/3D-CT images added important information regarding the visualization of specific structures, such as both condyles and their relationship with surrounding anatomical landmarks (17).

Jennet (18) found that in 56\% of cooperative patients, satisfactory skull radiographs were not obtained. Regarding the difficulty of controlling a distressed child, the need to position the head and the

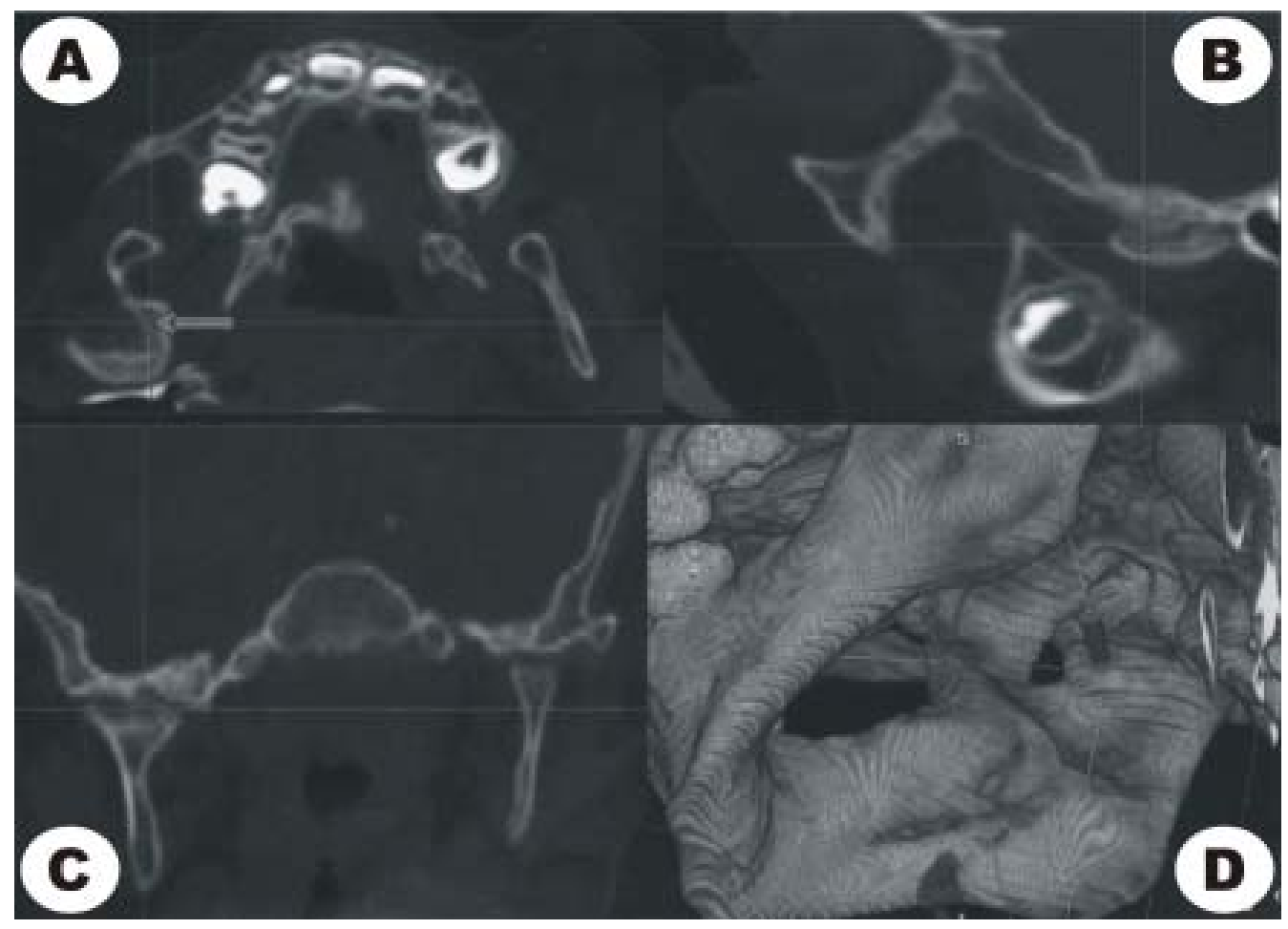

Figure 4. MPR-CT, in axial (A), sagittal (B), coronal (C), and 3D-CT bone protocol (D) views depicting simultaneous multiple images (using the crosshair tool) of the right TMJ ankylosis (arrow). 
overlap of multiple anatomic structures of the small pediatric skull, plain skull films become almost useless. The association of all these factors could lead to failure in diagnosis of any TMJ pathologic condition that may result in late complications, such as ankylosis and development of BMC. Functional disturbances of the TMJ have not been reported in most BMC cases. These cases have been diagnosed with radiographs that have been taken for other reasons. The use of plain films is usually carried out as the first option of facial evaluation (19), however the vast number of structures and their overlapping cause poor visualization of regions of interest, impairing a proper interpretation of images (20).

Although panoramic radiograph was a valid diagnostic tool in the diagnosis of BMC, conventional radiographs were not sufficient to reach a final diagnosis. It was essential to conduct CT assessment to rule out early stages of TMJ pathology (e.g. ostechondroma) (19). In the case hereby presented, the choice for CT scan depicts the advantages of this modality of imaging over other methods. As previously stated by El-Hakim (11) and Costa e Silva (20), axial and coronal CT images were of great value in illustrating the relation of the vital structures at the base of the skull to the ankylotic mass on the right side, the formation of the groove and the mediolateral heads onleft side, thus characterizing a true bifid mandibular condyle.

\section{RESUMO}

O côndilo mandibular bífido (BMC) é uma entidade incomum descrita na literatura e de etiologia controversa. Apesar da ausência de sintomatologia clínica, o radiologista deve estar alerta e deve ter conhecimento a respeito desta anormalidade, bem como suas implicações funcionais e mudanças morfológicas. A anquilose de articulação temporomandibular é uma patologia incapacitante com envolvimento do côndilo mandibular, fossa articular e base do crânio. A associação entre côndilo mandibular bífido e anquilose temporomandibular é rara e deve ser avaliada cuidadosamente. O objetivo deste artigo é relatar um caso simultâneo de côndilo mandibular bífido (BMC) e anquilose temporomandibular e descrever seus achados em tomografia computadorizada (CT).

\section{ACKNOWLEDGEMENTS}

To FAPESP/SP for granting a post-doctoral fellowship (2006/ 05251-8) to the author Marcelo Augusto Oliveira Sales.

\section{REFERENCES}

1. Gundlach KK, Fuhrmann A, Beckmann-Van der Ven G. The double headed mandibular condyle. Oral Surg Oral Med Oral Pathol 1987;64:249-253.

2. Hersek N, Ozbek M, Tasar F, Akpinar E, Firat M. Bifid mandibular condyle: a case report. Dent Traumatol 2004;20:184-186.

3. Stadnicki G. Congenital double condyle of the mandible causing temporomandibular joint ankylosis: report of case. J Oral Surg 1971;29:208-211.

4. Manganello-Souza LC, Mariani PB. Temporomandibular joint ankylosis: report of 14 cases. Int J Oral Maxillofac Surg 2003;32:24-29.

5. Remi M, Christine MC, Gael P, Soizick P, Joseph-Andre J. Mandibular fractures in children: long term results. Int $\mathrm{J}$ Pediatr Otorhinolaryngol 2003;67:25-30.

6. Toyama M, Kurita K, Koga K, Ogi N. Ankylosis of the temporomandibular joint developing shortly after multiple facial fractures. Int J Oral Maxillofac Surg 2003;32:360-362.

7. Blackwood HJ. The double-headed mandibular condyle. Am J Phys Anthropol 1957;15:1-8.

8. Eckelt U, Hlawitschka M. Clinical and radiological evaluation following surgical treatment of condylar neck fractures with lag screws. J Craniomaxillofac Surg 1999;27:235-242.

9. de Sales MA, do Amaral JI, de Amorim RF, de Almeida Freitas R. Bifid mandibular condyle: case report and etiological considerations. J Can Dent Assoc 2004;70:158-162.

10. Jordana X, Garcia C, Palacios M, Chimenos E, Malgosa A. Bifid mandibular condyle: archaeological case report of a rare anomaly. Dentomaxillofac Radiol 2004;33:278-281.

11. El-Hakim IE, Metwalli SA. Imaging of temporomandibular joint ankylosis. A new radiographic classification. Dentomaxillofac Radiol 2002;31:19-23.

12. Guven O. A clinical study on temporomandibular joint ankylosis. Auris Nasus Larynx 2000;27:27-33.

13. Linnau KF, Stanley RB Jr., Hallam DK, Gross JA, Mann FA. Imaging of high-energy midfacial trauma: what the surgeon needs to know. Eur J Radiol 2003;48:17-32.

14. Villarreal PM, Monje F, Junquera LM, Mateo J, Morillo AJ, Gonzalez C. Mandibular condyle fractures: determinants of treatment and outcome. J Oral Maxillofac Surg 2004;62:155-163.

15. Chacon GE, Dawson KH, Myall RW, Beirne OR. A comparative study of 2 imaging techniques for the diagnosis of condylar fractures in children. J Oral Maxillofac Surg 2003;61:668672; discussion 673.

16. Santos DT, Cavalcanti MGP. Osteosarcoma of the temporomandibular joint: report of 2 cases. Oral Surg Oral Med Oral Pathol Oral Radiol Endod 2002;94:641-647.

17. Santos DT, Silva APC, Vannier MW, Cavalcanti MG. Validity of multislice computerized tomography for diagnosis of maxillofacial fractures using an independent workstation. Oral Surg Oral Med Oral Pathol Oral Radiol Endod 2004;98:715-720.

18. Jennet B. Skull x-rays after recent head injury. Clin Radiol Imaging 1980;31:463-469.

19. Artvinli LB, Kansu O. Trifid mandibular condyle: a case report. Oral Surg Oral Med Oral Pathol Oral Radiol Endod 2003;95:251-254.

20. Costa e Silva APA, Antunes JLF, Cavalcanti MGP. Interpretation of mandibular condyle fractures using 2D- and 3Dcomputed tomography. Braz Dent J 2003;14:203-208.

Accepted October 10, 2006 